\title{
Application of PLS and TRIZ Method in Optimizing Customer Satisfaction Insurance of PT X
}

\author{
Kukuh winarso ${ }^{1}$, Dyah Ayuning Tyas ${ }^{2}$ \\ Departement of Industrial and Mechanical Engineering \\ University of Trunojoyo Madura \\ Bangkalan, Indonesia \\ ${ }^{1}$ kukuh.winarso@trunojoyo.ac.id, ${ }^{2}$ dyah.ayunin@gmail.com
}

\begin{abstract}
Partial Least Square is a more flexible SEM (Structural Equation Modelling) method because it does not assume normally distributed data such as CB-SEM. PLS can also be applied to reflective and formative models with smaller sample quantities. In this study, PLS serves as a predictor to look for variable quality of insurance services including tangible, competency, corporate image, personalized financial planning, technology and assurance that significantly influence customer satisfaction PT X. Research shows only significant assurance dimension and positive effect on customer satisfaction, while for assurance indicator is all significant value which is only 1st assurance indicator is not used because of multicollinearity. After further analysis, satisfaction scores for the four assurance indicators there is a variation between satisfied and very satisfied and the average satisfaction score itself. Unequal customer satisfaction is a problem for the company because it is used the TRIZ (Theory of Invention Problem Solving) method, a method of solving the problem to achieve the best solution with the aim of increasing customer satisfaction from the indicator that has been proven significant according to PLS method. Through the matrix of contradiction between improving feature and worsening feature, the result of the 28th and 1st inventive principles is the selection of the same solution in the form of automatic call center making to optimize the satisfaction of AS2, AS3, AS4, and AS5.
\end{abstract}

Keywords_PLS; Insurance; PT X; TRIZ

\section{INTRODUCTION}

People are increasingly aware of the importance of safety needs [1]. It is known from the average per capita expenditure per month for tax utilization and insurance premium in East Java which shows an increase. But ironically, the growth rate of insurance in Bangkalan City is inversely proportional to the decline in insurance growth and the lowest compared to other districts in Madura Island even insurance growth value in Bangkalan below the average growth of insurance in East Java. In addition, the insurance sector in Bangkalan is the sector with the lowest growth rate compared to other sectors. Nevertheless, there is still hope to increase the growth of the sector because although the least decrease in insurance growth in Bangkalan is positive. The selection of insurance PT X as the object of this study is due to the data of top ten market leader insurance companies in Indonesia, PT X has a lower share than other insurers and PT $X$ in Bangkalan Branch itself there is a decrease in premium holders or customers from 2016 to 2017 now so it must be done a research.

The existence of this problem encourages researchers to conduct research that can improve customer satisfaction so that the growth rate of insurance in Bangkalan can increase from the previous year in the future. The method used in this research is Partial Least Square (PLS) and Theory of Invention Problem Solving (TRIZ). PLS is used to select the dimensions of service quality and produce dimensions that significantly affect customer satisfaction. While, TRIZ will make improvements to the problems that arise in its dimension.

\section{LITERATURE REVIEW}

\section{A. Insurance}

Insurance is an engagement between two parties namely the insurer (insurance company) and the insured (customer) where the insurer is required to provide compensation to the insured in the form of money in the event of a disaster guaranteed by the policy agreed by both parties. This compensation is a reciprocal or fee of a risk transfer in the form of premiums paid by the customer or the underwritten to the insurer.

1) Life Insurance: Life insurance is coverage with the object of an insured person and insured is the life of a person. Except for life insurance, guarantees can be extended with health and accidents. This insurance provides assurance of protection in the form of financial risk transfer of a person's death or loss of income opportunities in old age or for family financing. Life insurance is different from general insurance, this type of insurance provides a guarantee for loss of non-life property.

\section{2) Dimensions of Life Insurance Servqual}

a) Tangibles: All indicators or components included in this dimension relate to the provision of facilities and physical communication materials.

b) Competence: This component talks about the components of service providers to perform services in a dependent and efficient manner and also about their willingness to provide hassle-free and fast services. 
c) Corporate Image: This component isconcerned with creating an overall image of insurance company organizations in the eyes of customers.

d) Technology: All components included in this dimension are related to the use of modern tools (technology) in the provision of services that facilitate customer service.

e) Personalized Financial Planning: All the variables contained in this dimension illustrate the handling of preference changes by providing flexible solutions and convertibility options as well as the provision of personal services.

f) Assurance: All variables in this dimension assure the policyholder with the knowledge of the agent and the agency's ability to inspire confidence and belief.

3) Satisfaction: Satisfaction is the perception of the customer that his expectation of the product or service consumed or used has been fulfilled There are numerous expert ideas about the dimensions of satisfaction, which can be summarized into the following sections.

4) Partial Least Square (PLS): PLS is one multivariate statistical technique that performs modeling between the dependent variable and independent variable multiple. This method is a variance-based SEM approach that can simultaneously examine the measurement and structural models. The fundamental difference between PLS and SEM is that SEM is confirmatory so that it functions to confirm the theory of previous research that there is a strong theoretical foundation, while the PLS although mainly for exploratory research can also confirmatory research and not necessarily based on strong theory, requires assumption of data normality and can be identified which variable acts as the main determinant.

\section{B. TRIZ}

TRIZ [2] stands for Russian Teoriya Resheniya Izobreatatelskikh Zadatch. This method was developed by G.S. Altshuller and his colleagues from the Soviet Union. How TRIZ work is finding a problem before resolving the issue. What is indicated by finding a problem is to evaluate the initial solution to overcome the problem until found the best solution that takes into account the risks and impacts to find the final solution that can really fix the problem.

\section{RESEARCH METHODS}

\section{A. Research Variables}

The research variables consist of the independent variable (Exogenous) and the dependent variable (Endogen). The independent variables in this study are the dimensions of life insurance servqual including tangibles (TA), competence (CO), corporate image (CI), technology (TE), personalized financial planning (PF) and assurance (AS). Here are the code and reference source for each service quality indicator that will be requested to the respondent through the questionnaire.
Dependent variable (Endogenous), Endogen variable in this research is customer satisfaction.

\section{B. Place of Research}

The research was conducted by filling out the questionnaire online by using google form feature after the customer contacted via social media that is Whatsapp or second alternative is to visit the customer's address which is in PT X Bangkalan Branch, the area based on the list of addresses that have been obtained by researchers from and on permission the PT X Bangkalan.

\section{Model Outline}

It is apprehended that six dimensions of life insurance servqual which includes assurance, tangible, personalized financial planning, competence, corporate image, and technology have a significant direct positive effect on customer satisfaction. The measurement model used in this study is a reflective measurement model that each indicator or observative variable is the cause of any latent variables described in the framework of this model. The framework of this model was adopted from Siddiqui's research, 2010 with the difference in this study lies in the use of latent variables of unsatisfied customer satisfaction.

\section{Hypothesis}

Hypothesis testing is done by Bootstrap resampling method with the minimum bootstrap count of 1000 . The hypothesis used is as follows.

The hypothesis for an outer model is:

H0: $\lambda \mathrm{i}=0$ (to- $\mathrm{i}$ indicator is insignificant)

$\mathrm{H} 1: \lambda \mathrm{i} \neq 0$ (to-i indicator is not insignificant)

The statistical hypothesis for an inner model is:

H0: $\gamma \mathrm{i}=0$ (the exogenous variable to- $\mathrm{i}$ is not significant)

$\mathrm{H} 1: \gamma \mathrm{i} \neq 0$ (the exogenous variable to- $\mathrm{i}$ is significant)

Statistics test: t-test; $p$-value $\leq 0.05$ (alpha 5\%); significant. Outer model is significant: the indicator is valid. Inner model is significant: there is significant influence.

\section{E. Settlement Method (Validity and reliability questionnaire)}

If $r_{\text {count }}>0.6$ then the questionnaire tested is valid. If there is an invalid statement item, then the improvements made is to improve the language statement that is more communicative and easier to understand respondents.

While for reliability test is useful to show the consistency level measurement result of a measuring instrument in research, where measuring instrument in this research is item statement in the questionnaire. If $r_{\text {count }}>0.6$ then the questionnaire tested is reliable.

1) PLS Test: Here is the result of the partial least square test (PLS). 
TABLE I. EVALUATION REQUIREMENTS OF PARAMETER MODELS

\begin{tabular}{|c|c|}
\hline Criteria & Requirement \\
\hline \multirow{2}{*}{ R-Square } & $\begin{array}{c}0.67,0.33, \text { and } 0.19=\text { Strong model, Moderate, } \\
\text { and Weak }\end{array}$ \\
\cline { 2 - 2 } & $\begin{array}{c}0.75,0.5, \text { and } 0.25=\text { Strong model, Moderate, } \\
\text { and Weak }\end{array}$ \\
\hline Effect Size $f^{2}$ & $0.02,0.15$, and $0.35=$ Small, Medium, and Large \\
\hline $\begin{array}{c}Q^{2} \text { Predictive } \\
\text { Relevance }\end{array}$ & $\mathrm{Q}^{2}>0$ model has predictive relevance \\
\hline $\begin{array}{c}\text { Significant (two- } \\
\text { tailed) }\end{array}$ & $\begin{array}{c}\text { T-Value } 1.65 \text { (sig. 0.1), } 1.96 \text { (Sig. 0.05), and } 2.58 \\
\text { (Sig. 0.01) }\end{array}$ \\
\hline
\end{tabular}

TABLE II. TERMS OF EVALUATION OF STRUCTURAL MODELS

\begin{tabular}{|c|c|c|}
\hline $\begin{array}{l}\text { Validity and } \\
\text { Realibility }\end{array}$ & Parameter & Requirement \\
\hline \multirow{2}{*}{$\begin{array}{l}\text { Convergent } \\
\text { Validity }\end{array}$} & Loading Factor & $>0.70$ \\
\hline & $\begin{array}{l}\text { Average Variant } \\
\text { Extracted }\end{array}$ & $>0.50$ \\
\hline \multirow[b]{2}{*}{$\begin{array}{l}\text { Discriminant } \\
\text { Validity }\end{array}$} & Cross Loading & $>0.70$ \\
\hline & $\begin{array}{l}\text { Root Square AVE and } \\
\text { correlation between } \\
\text { laten construct }\end{array}$ & $\begin{array}{c}\text { Root Square AVE > } \\
\text { correlation between } \\
\text { laten construct }\end{array}$ \\
\hline \multirow{2}{*}{ Realibility } & Cronbach Alpha & $>0.70$ \\
\hline & Compossite realibility & $>0.70$ \\
\hline
\end{tabular}

The GoF Index analyzes to evaluate measurement models and structural models as well as simple measurements for the whole of the model predictions.

$$
G o F=\sqrt{\overline{\operatorname{Com}} \times \overline{R^{2}}}
$$

Com is known as the average communality index and $\mathrm{R} 2$ is the average $\mathrm{R}$ squares. The recommended communal value is 0.5 and $\mathrm{R} 2$ is $0.02=$ small, $0.13=$ medium and $0.26=$ large. So, the resulting GoF value is $0.1=$ small, $0.25=$ medium and $0.36=$ large.

2) TRIZ Method: In the TRIZ method, contradictory analysis consists of improving feature and worsening feature analysis.

Improving features is an evaluation of the initial solution by making possible positive impacts if the initial solution is applied to the service system. The vertical direction in the matrix contradiction.

Worsening feature is an evaluation of the initial solution by raising the risks or obstacles that may arise and must be overcome if you want to realize the initial solution. The direction is horizontal in the contradiction matrix.

The next step is to look for the inventive principles of meeting the parameters of improving feature and worsening feature techniques in contradiction matrices. Inventive principles are alternative solutions presented by TRIZ.

\section{DISCUSSION}

\section{A. Validity and Reliability Test}

Test of validity and reliability of the questionnaire on presampling was done by distributing questionnaires to 30 respondents. The result of the validity test shows that all questionnaire indicators have sig (2-tailed) under 0.05 or Pearson value above r-table so the statement in the questionnaire is valid. While the results of the reliability test showed a score of 0.754 from the number of respondents as many as 30 people. This value is above 0.6 so the statement in the questionnaire is stated to be reliable.

\section{B. Profile of Respondents}

All respondents feel satisfied with the quality of service and satisfaction aspects provided by PT $\mathrm{X}$ insurance which can be seen from the average score per indicator that mostly has an average value of 2.5-3.25.

\section{Test Measurement Outer Model (Measurement Model)}

1) Convergent Validity: Here is the output of convergent. The indicator is reliable if it meets a score of at least 0.5 in scale-up research on social studies using a questionnaire. Fig. 1 below describes Outer loading PF3.

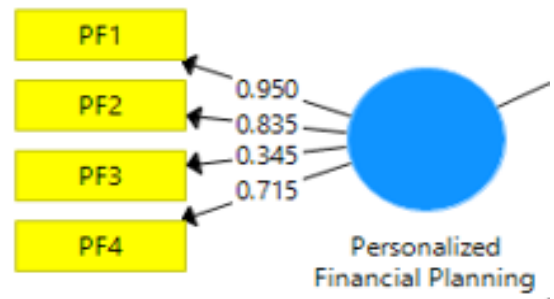

Fig. 1. Outer loading PF3

It is known that the value of outer loading PF3 with its own construct (Personalized Financial Planning) is 0.345 . This value is below the specified requirement of 0.5 so that the PF3 indicator must be eliminated so as not to affect the outcome.

2) Discriminant Validity: Cross loading value of CI1 and CI5 on the construct of corporate image and PU2 to the customer satisfaction construct are not greater than the cross loading value between CI1 to tangible, and CI5 and PU2 to the assurance construct so it is inferred not to meet the requirements of cross loading and the indicator must be eliminated from the path diagram in the PLS visual model. However, this elimination is done after looking at the $\mathrm{p}$-value to see the significance of the indicator which should be below 0.05 and the effect of the existence of the indicator on the result of $\mathrm{R}^{2}$.

Discriminant validity can also be observed by comparing the AVE square root value with the correlation value between constructs (Fornell Larcker Criterium Test). The results are answered if the AVE square root is greater than the correlation value of a construct to another construct. As is comprehended the square root of AVE is the value of the correlation between the construct and the construct itself, so ideally the construct correlation for the construct with the construct itself must be the greatest compared to the other constructs. 
It is known that the highest value of construct correlation is on the corporate image construct and customer satisfaction not on the construct itself but on another construct that is assurance. This correlation value also has a value below the AVE square root so it is not eligible and can be eliminated if it has a p-value below 0.05 .

\section{Construct Reliability and Validity}

TABLE III. RELIABILITY AND VALIDITY EACH INDICATOR

\begin{tabular}{|l|c|c|c|}
\hline \multicolumn{1}{|c|}{ Indicator } & $\begin{array}{c}\text { Composite } \\
\text { Reliability }\end{array}$ & $\begin{array}{c}\text { Cronbach's } \\
\text { Alpha }\end{array}$ & Alpha \\
\hline Assurance & 0.848 & 0.758 & 0.587 \\
\hline Competency & 0.869 & 0.798 & 0.626 \\
\hline Corporate Image & 0.847 & 0.751 & 0.589 \\
\hline $\begin{array}{l}\text { Customer } \\
\text { Satisfication }\end{array}$ & 0.858 & 0.789 & 0.552 \\
\hline $\begin{array}{l}\text { Personalized } \\
\text { Financial Planning }\end{array}$ & 0.877 & 0.785 & 0.706 \\
\hline Tangible & 0.853 & 0.741 & 0.663 \\
\hline Technology & 0.908 & 0.848 & 0.768 \\
\hline
\end{tabular}

Based on Table III it is known that the value of composite reliability, Cronbach's alpha and AVE for all indicators are eligible.

\section{E. Structural Model Inner Model (Structural Model)}

1) P-value or T-value: To know the level of influence or significance of the indicator with the construct and between exogenous constructs with endogenous constructs. Viewed from $\mathrm{p}$-value then the value must be $\mathrm{p}$-value $\leq$ sig. Because the level of significance used is 0.05 then the value of $p$-value must be $\mathrm{p}$-value $<0,05$.

There are some indicators that are not valid on some criteria, but according to the significance test, all the indicators are able to explain well each construct because of the $p$-value $\leq$ sig. However, since the presence of PF3 and CI1 in the model makes the coefficient of determination of customer satisfaction (R2) as a low endogenous construct which is known to researchers after trial and error, it is finally concluded that only PF3 and CI1 indicators are dropped from the initial model.

2) $R^{2:}$ The coefficient of determination or value that states how large a collection of exogenous constructs can affect customer satisfaction (endogenous constructs). The value obtained in the initial model is 0.749 which is included in the strong category [3].

3) $f^{2}$ initial model: The effect size of the endogenous latent variable to the exogenous latent variable of 0,501 for assurance. The $\mathrm{f}^{2}$ value is strong. But the significance value > 0,05 so it is invalid.

4) $Q^{2}$ model start: Test of the kindness of structural model can be seen from the value of $\mathrm{Q}^{2}$. This value is calculated from the value of $\mathrm{R}^{2}$ with the mathematical formula and does not come out in the form of smart PLS software output.

$$
\mathrm{Q}^{2}=1-\left(1-\mathrm{R}^{2}\right)
$$

$$
\mathrm{Q}^{2}=1-(1-0.749)=1-0.251=0.749
$$

Then $\mathrm{Q} 2=\mathrm{R}^{2}$. Since $\mathrm{Q}^{2}>0$ means the model has predictive relevance

5) The initial Path Coefficient model: The value of the latent variable coefficient of assurance towards customer satisfaction is $70,4 \%$ which means strong and also positive, it implies that increasing assurance aspect is getting bigger and also customer satisfaction. While for competency, personalized financial planning and technology have positive influence but not significant. For corporate image and tangible have a negative but not significant influence.

Here is the output of smart PLS which is the final model has eliminated the indicator that is considered not qualified PLS.

TABLE IV. COMPARISON OF START AND END MODELS

\begin{tabular}{|l|l|c|c|c|}
\hline & & $\begin{array}{c}\text { Initial } \\
\text { Model }\end{array}$ & $\begin{array}{c}\text { Final } \\
\text { Model }\end{array}$ & Information \\
\hline $\mathrm{R}^{2}$ & $\begin{array}{l}\text { Customer } \\
\text { Satisfication }\end{array}$ & 0.749 & 0.755 & $\begin{array}{c}\text { Strong } \\
\text { model }\end{array}$ \\
\hline $\begin{array}{l}\text { P-value for } \\
\text { Path } \\
\text { Coefficient }\end{array}$ & AS2 > Assrance & 0.013 & 0.012 & Significant \\
\hline & AS2 > Assrance & 0.000 & 0.000 & Significant \\
\hline & AS2 > Assrance & 0.000 & 0.000 & Significant \\
\hline & AS2 > Assrance & 0.001 & 0.000 & Significant \\
\hline & $\begin{array}{l}\text { Assurance }> \\
\text { Customer } \\
\text { satisfication }\end{array}$ & 0.007 & 0.006 & Significant \\
\hline $\begin{array}{l}\text { Path } \\
\text { Coefficient }\end{array}$ & $\begin{array}{l}\text { Assurance > } \\
\text { Customer } \\
\text { satisfication }\end{array}$ & 0.681 & 0.704 & $\begin{array}{c}\text { Strong } \\
\text { influence }\end{array}$ \\
\hline f2 & Assurance & 0.501 & 0.508 & $\begin{array}{c}\text { Strong effect } \\
\text { size }\end{array}$ \\
\hline $\begin{array}{l}\text { P-value for } \\
\text { f2 }\end{array}$ & Assurance & 0.404 & 0.332 & $\begin{array}{c}\text { Not } \\
\text { Significant }\end{array}$ \\
\hline \multicolumn{4}{|l|}{ GoF $=\sqrt{0.641 \times 0.755}=\sqrt{0.484}=0.696$} \\
\end{tabular}

The criteria for GoF values are 0.1 for GoF small, 0.25 for medium GoF and 0.36 for large GoF. Since the GoF value for the model is 0.696 then the overall model prediction is declared good.

\section{F. Hypothesis testing}

For assurance aspect, p-value 0,002 <0,05 So Accept H0 which means there is the significant relation of assurance with customer satisfaction. Fig. 2 below shows PLS and Path Coefficient model. 


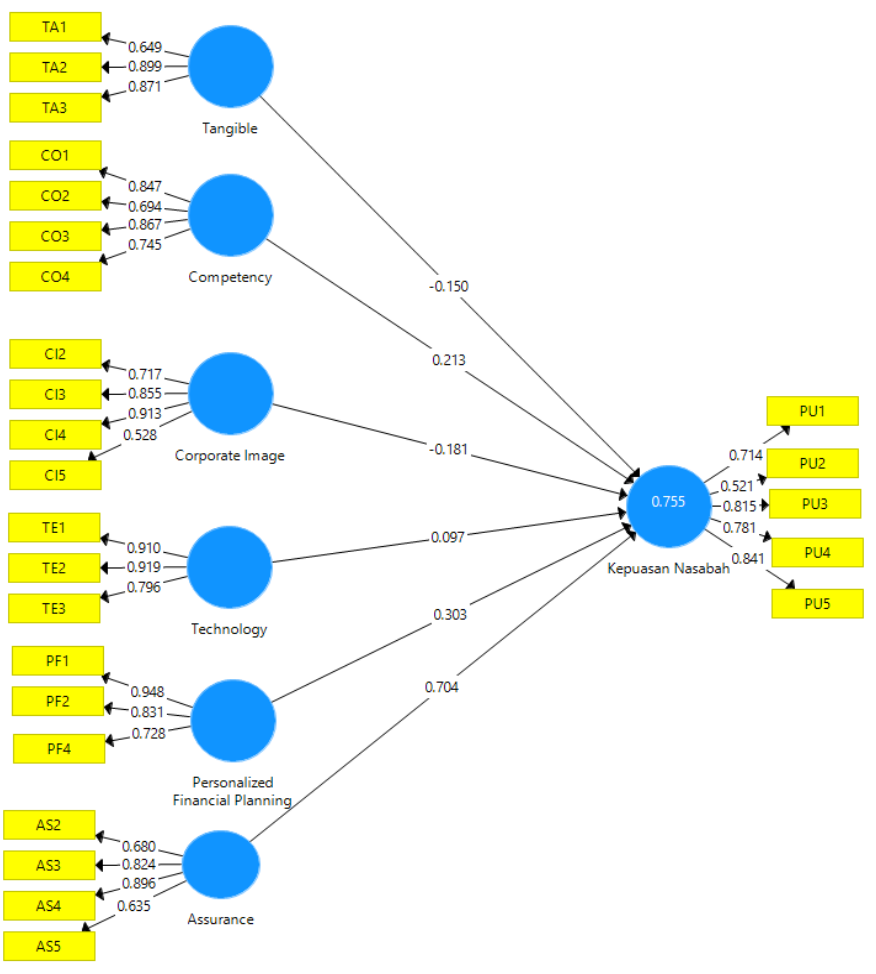

Fig. 2. PLS and Path Coefficient model

\section{G. TRIZ Method}

TABLE V. INVENTIVE PRINCIPLES INDICATORS

\begin{tabular}{|c|c|c|c|c|c|}
\hline $\begin{array}{c}\text { Improving } \\
\text { Feature }\end{array}$ & $\begin{array}{c}\text { Parameter } \\
\text { Service }\end{array}$ & $\begin{array}{c}\text { Worsening } \\
\text { Feature }\end{array}$ & $\begin{array}{c}\text { Parameter } \\
\text { Service }\end{array}$ & $\begin{array}{l}\text { Inventive } \\
\text { Principle }\end{array}$ & Choosen \\
\hline $\begin{array}{l}\text { Quick } \\
\text { response with } \\
\text { the wishes of } \\
\text { potential } \\
\text { customers }\end{array}$ & $\begin{array}{c}\text { \#Productivity } \\
\text { (39) }\end{array}$ & $\begin{array}{l}\text { Should be } \\
\text { followed by } \\
\text { improveme } \\
\text { nt of } \\
\text { information } \\
\text { services }\end{array}$ & $\begin{array}{c}\text { \#Equipment } \\
\text { complexity } \\
(36)\end{array}$ & $\begin{array}{l}12,17 \\
28,24\end{array}$ & \#28 \\
\hline $\begin{array}{l}\text { Agent ability } \\
\text { creates a } \\
\text { familiar } \\
\text { atmosphere }\end{array}$ & $\begin{array}{c}\text { \#adaptability } \\
\text { (35) }\end{array}$ & $\begin{array}{l}\text { Agents } \\
\text { must be } \\
\text { trained }\end{array}$ & \#Power (21) & $19,1,29$ & $\# 1$ \\
\hline $\begin{array}{l}\text { Agent do } \\
\text { research to } \\
\text { find more } \\
\text { applicable } \\
\text { forms of } \\
\text { information }\end{array}$ & $\begin{array}{l}\text { \#Measure- } \\
\text { ment } \\
\text { accurate (28) }\end{array}$ & $\begin{array}{l}\text { Employee } \\
\text { break time }\end{array}$ & $\begin{array}{c}\text { \#Loss of time } \\
\text { (25) }\end{array}$ & $\begin{array}{l}24,34 \\
28,32\end{array}$ & \#28 \\
\hline $\begin{array}{l}\text { Agents } \\
\text { provide the } \\
\text { totally of } \\
\text { services by } \\
\text { providing } \\
\text { flexibility to } \\
\text { schedule } \\
\text { premium } \\
\text { payments }\end{array}$ & \#Style & $\begin{array}{l}\text { Customers } \\
\text { flexibility } \\
\text { provided by } \\
\text { the agent }\end{array}$ & $\begin{array}{l}\text { \#Weight of } \\
\text { moving } \\
\text { object }(1)\end{array}$ & $\begin{array}{c}8,1,37 \\
18\end{array}$ & $\# 1$ \\
\hline
\end{tabular}

The same number of indicators is the 28th inventive principles for AS2 and AS4 and the $1^{\text {st }}$ inventive principles for AS3 and AS5. So these two inventive principles that will be generated by researchers to get the best solution. The selection of the same inventive principles is based on the opinion of Savransky [4] that occurs at least twice because in order to focus on the quality improvement that will be done.

Final solutions for AS2 and AS4 [5] are (1) making FAQs (Frequently Asked Questions) or serialized video explanations about PT X and other insurances that customers often ask in traditional service (2) making an auto center that automatically answers customer questions without cost, (3) creation of community forum for insurance customers (clearer structure, with real-time communication) through social media WhatsApp and occasional gathering.

While the final solution for AS3 is (1) prioritize customers who have high loyalty seen from the existence of repurchase by eliminating other insurance products that are quiet enthusiasts or interested customers who are not loyal. (2) The division of the agent's task becomes simpler, ie for product information can be through calling the automated call center system and also (3) the customer can choose the agent as he wishes to pay the claim or explain the less obvious policy.

The solution for the four selected indicators is the creation of an automated call center. This selection is based on the solution equations on AS2, AS3, AS4 and AS5 indicators.

\section{CONCLUSION}

- Variable quality of insurance services include tangible, competency, corporate image, personalized financial planning, technology, and assurance only one variable that is assurance that significantly affects the satisfaction of PT $\mathrm{X}$ Bangkalan insurance customers with the $\mathrm{p}$-value of 0.002 .

- The average AS2, AS3, AS4 and AS5 satisfaction scores are in the 3 rd range with the answer variations dominated between 3 and 4 . Due to the problem of service quality perceptions, the TRIZ method will create a solution to increase the average score of satisfaction customers to be very satisfied The end result of TRIZ is the application of 28th inventive principles for increasing satisfaction in AS2 and AS4 indicators, while for AS3 and AS5, the inventive principles used are 1st inventive principles.

- Priority solutions to optimize customer satisfaction on AS2, AS3, AS4 and AS5 indicators is by making the automatic call center.

\section{REFERENCES}

[1] S. Darwin and Y.S. Kunto, "Analysis of Service Quality Influence on Customer Loyalty with Customer Satisfaction and Trust as Intervening Variable at Manulife Indonesia-Surabaya Life Insurance," J. of Petra Market. Manag., vol. 2, pp. 1-12, 2014.

[2] G.S. Al'tshuller, The innovation algorithm: TRIZ, systematic innovation and technical creativity, Worcester: Technical Innovation Center Inc., 2007.

[3] J.F. Hair, et al., A Primer On Partial Least Squares Structural Equation Modeling (PLS SEM), California: Sage Publication Inc., 2014.

[4] S.D. Savransky, Engineering of creativity: Introduction to TRIZ methodology of inventive problem solving, Florida: CRC Press, 2000.

[5] J. Zhang, K.H. Chai, and K.C. Tan, "40 Inventive Principles with applications in Service Operation Management," [Online], Available: https://triz-journal.com/40-inventive-principles-applications-serviceoperations-management/. [Accessed: 27-Aug-2018] 